\title{
Innovative Women's Poetry in the United Kingdom
}

\section{Stephen Mooney}

\begin{abstract}
This article presents an overview, from a publishing and poetics perspective, of innovative women's poetry in the UK in the present day, examining some of the issues around access and representation of women's writing in that context. Conferences, festivals and anthologies are considered, alongside information from poetry publishing houses in the field, including a reading of the current scape of innovative women's writing in the UK from the author's perspective as an editor of Veer Books. The convergence of transgender identity and that of women in key issues of identity space and visibility in terms of innovative writing (both practices and spaces) is also proposed.
\end{abstract}

\section{Keywords}

Women's Writing, Innovative Writing, Innovative Poetry, Experimental Poetry, UK Poetry, Gender, Feminism, Trans, Trans Feminism, Transphobia, Poetry Anthology, Poetry Festival, Poetry Publishing, Veer Books, Postmodern Writing

Dr Stephen Mooney

University of Surrey

School of English and Languages, FASS, University of Surrey, Guildford GU2 7XH.

01483683121

s.mooney@surrey.ac.uk

\section{Brief Bio}

Stephen Mooney is a lecturer in Creative Writing at the University of Surrey, where he was also the Poet in Residence in 2012/13. He is an associate member of the Contemporary Poetics Research Centre at Birkbeck, and co-runs the small poetry press, Veer Books. His poetry has appeared in various places and web-places, including as part of the performative poetry grouping 'London Under Construction'. DCLP and Shuddered, the latter co-authored with Aodán McCardle and Piers Hugill, were published by Veer Books in 2008 and 2010 respectively, and The Cursory Epic by Contraband Books in 2014. 
Innovative Women's UK Poetry

\section{Innovative Women's Poetry in the UK}

What kind of an overview is this going to be? With a self-identified gay male poet, publisher and academic, writing on women's poetry, already this is a contentious proposition for some readers. Rather than deliver a theoretical Gender Studies approach, well rehearsed as the issues are within the pages of this and other gender focused journals, this article will be presented primarily from a publishing perspective, with specific academic application. I will not, as such, go into much of the significant and growing body of quality critical writing focusing on specific poetic texts in this area such as that by Wagner (2007), Critchley (2011), Kennedy and Kennedy (2013), Skoulding (2013) and Thurston (2015). The importance of this is noted, both academically and in its crucial function cementing, encouraging and supporting the validity and vibrance of women's innovative writing practices in the UK. I also note the importance of relevant non-academically institutionalized poetics that poetic communities have generated, some of which I will mention later in this piece.

So, with this in mind, what do I mean by 'Innovative'?

The term is an indistinct catchall phrase that needs pinning down somewhat in order to distinguish it from the equally indistinct phrase 'mainstream'. While neither phrase is particularly helpful in some ways, the distinction, where it can be drawn, is relevant to the poetry and the poetry community I wish to talk about here. In the editorial introduction to the first issue of the Journal of British and Irish Innovative Poetry, Robert Sheppard and Scott Thurston provide a working definition, saying of this poetry that it has appeared

under various names, whether that be: avant-garde, experimental, formally 


\section{Innovative Women's UK Poetry}

innovative, linguistically innovative, neo-modernist, non-mainstream, postavant, postmodernist, the British Poetry Revival, the parallel tradition, or even, that venerable survival from the 1960s, underground poetry [...] Particular areas of these fields have been known as the Cambridge School, the London School, concrete poetry and performance writing. (Sheppard and Thurston 2009: 3)

They make the point that all of these terms are contestable, and we could readily add terms like alternative poetry, Alt-poetry, Language poetry, conceptual poetry and more to this list.

What links these poetries together for me is their exploratory approach to language and poetic form, amongst other things, and their existence (generally) outside of the canonical mainstream of publically funded and endorsed poetry that organizations like the Arts Council in Britain promote, and celebrity poets such as the poet laureate, Carol Ann Duffy, represent.

In terms of thinking about women's poetry in the UK within this context, what then do I mean? We run into numerous problems here; aside from the obvious 'who decides what is innovative and what is not' issue, 'innovative women's poetry in the UK' is not identifiable as one discrete thing. Many of the authors we could identify as innovative UK women poets are widely published outside of the UK through presses located across the world, especially in North America (Wendy Mulford, Maggie O’Sullivan, Sophie Robinson, and Carol Watts, for example). Likewise many non-UK women writers in this field are published in the UK through UK publishing houses. Alice Notley is a good example here. A senior innovative poet, 


\section{Innovative Women's UK Poetry}

American in nationality, currently living in France, she has been and remains an importantly influential figure to UK innovative poetry, doing readings, publishing in UK relevant journals and anthologies, and featuring at events such as the Constellation: Alice Notley symposium held at Birkbeck’s Poetics Centre in 2008. She has been widely published in the US, and elsewhere, while we at Veer Books have published a book by her, Above the Leaders, in the UK.

We should also consider non-UK nationals who are based and write in the UK in this field, such as Caroline Bergvall, Andrea Brady or Frances Kruk, and the many UK poets who currently live or at any given point have lived abroad and are published in their country of residence, here in the UK, and indeed further afield (Fiona Templeton, Catherine Hales or Amy De'Ath, for example). As such there is no 'stable pot' of writers who we can identify as UK innovative women poets - the innovative poetry scene is transnational, interconnected, interdependent and in constant communication and exchange.

\section{Doing it Live}

In terms of my own personal involvement in the discussion of women's innovative writing, I was involved in organizing, as part of the Contemporary Poetics Research Centre at Birkbeck, with William Rowe, Carol Watts, Aodán McCardle, Piers Hugill and Redell Olson, a small scale Forum on Women Writers in 2005, where twenty five or so participants discussed some of the issues around women writers and their experience of the academic and publishing structure in UK Innovative Poetry. We 


\section{Innovative Women's UK Poetry}

published some material from this, and in response to this, on the Readings website. ${ }^{1}$ Some very important issues around male attitudes towards women writers, the unsuitability of many reading venues for some women writers, the hierarchically male structures of the publishing world, and the potential for sexual harassment and intimidation of women writers on the innovative poetry scene were raised, amongst other things. That said, I'm not sure we came out of this forum as a community having advanced very far.

One of the responses to issue of this sort has been women focused groupings such as the Bedford Square group, set up by Andrea Brady, Redell Olson and Lucy Sheerman. Brady says of it that it was

designed specifically to provide an environment in which women could develop and discuss their work, getting critical feedback and supporting each other's various practices. We recognized that the existing forms of exchange for poetry had for a long time seemed enervated and dull. Why should anyone, let alone a creative and difficult woman working between media and with the conflicts of the world and her own utility banging in her poetic cochlea, want to sit on a hard chair in a carpeted room above a pub listening to the same five or six old men with only themselves for audiences? The poetry reading is too often an anti-social event, whose management is anti-creative. If we worked harder to organise them they could be regarded as a pleasure, rather than just

\footnotetext{
${ }^{1}$ Available at: http://www.bbk.ac.uk/readings-old/r2/readings2.html (accessed 15
} April 2015) 


\section{Innovative Women's UK Poetry}

an obligation to replace mass on Sundays. (Wagner 2007: para 8)

In the same forum, Geraldine Monk, commenting on why there weren't more women writing experimental poetry say that:

One reason cited more than once is that women didn't like where 'experimentation' took place: in smoky upstairs rooms of pubs with a small audience. Oh well. The small audiences could be a drag but mainstream poetry also took place in smoky upstairs rooms in pubs with small audiences so I don't really think too much can be made of that. (para 20)

If nothing else, this emphasizes that there are multiple approaches to issues around visibility and access that women writers experience in the innovative poetry world in the UK, and of the multiple responses proposed few, if any, are without their vociferous critics. Women only spaces in the innovative poetry world in the UK have been contested and challenged, as have spaces that do not have active policies in place to attract women writers. This remains the case today, with many, particularly male, commentators and publishers identifying a public engagement with gender as highly problematic. This is not necessarily a bad thing, I feel. We have not reached parity yet, in terms of women's representation, if that is to be a goal. Gender should not be, perhaps, an uncomplicated, reducible collection of ideas and experiences that can be 'put to rest' at some point. In the context of gender underrepresentation and inequality an engagement with it should be problematic. The points being raised by women writers do seem to have to have been made again and again in order to effect the changes that we see today. Much has been hard won through this 'again and again', 
Innovative Women's UK Poetry

and while not an ideal way to move forward in some senses, it does keep gender issues from the complacent space of 'we have done enough'.

Since this 2005 forum, there have been two major conference festivals focusing on innovative women's writing in poetry in the UK, the Contemporary Experimental Women's Poetry Festival in 2006 at Cambridge, organized by Emily Critchley, and the Women's Innovative Poetry \& Cross-Genre Festival at Greenwich, organized by Critchley and Carol Watts of Birkbeck in 2010.

With the former, Critchley stated that the festival

was intended to highlight and celebrate past and present Cambridge talent, as well as the extraordinary depth and range of experimental work currently being produced by women around the world [...] The aim was to introduce students and the public to the impressive number of women writing today, as well as to establish a network of exchange and support between younger and more established poets, and those writing in different parts of the world. (Critchley 2007)

It brought together a diverse and exciting range of writers in a celebratory way rather than cultivating an offensive (in its militaristic sense) or defeatist rear-guard action feel to the occasion. ${ }^{2}$

\footnotetext{
${ }^{2}$ Selected poetry and papers from this festival are available at the How2 website at https://www.asu.edu/pipercwcenter/how2journal/vol_3_no_1/cambridge/, while
} 


\section{Innovative Women's UK Poetry}

As Catherine Wagner notes in 'Women and the UK Experimental/Avant-Garde Poetry Community - A Cross-Atlantic Forum', in terms of its visibility, the festival was 'followed by only one public commentary, by Elizabeth James, on the UK Poetry list' (Wagner 2007: para 2), a state of affairs that emphasizes, for Wagner, an important part of the difficulty facing women in innovative writing circles at the time.

In the advent of the Women's Innovative Poetry \& Cross-Genre Festival four years later, the ground had changed somewhat. The Journal of British and Irish Innovative Poetry, founded in 2009, dedicated a special issue to the conference, guest edited by Critchley (JBIIP, 2011, 3 (2)), for example. The festival was a great success and very well attended, and combined a far wider cohort of UK and International work than its predecessor. Its focus was not just on women's poetry but also on the theme of crossgenre and collaboration, and this combination proved popular. Of the forty-six reading and academic-paper 'slots' at the three-day event over half (55\%) were taken by female UK writers, while a higher percentage again (63\%) were taken by UK writers as a whole (both male and female), indicating, amongst other things, a swelling of interest in UK women's innovative poetry in the UK. ${ }^{3}$

recordings of the readings are available on the Meshworks website at http://www.orgs.miamioh.edu/meshworks/archive/CEWPF/CEWPF.html and on the Archive of the Now website at http://www.archiveofthenow.org/reading-series/?i=2.

${ }^{3}$ Selected recordings of the readings from this festival are available at the Openned website at http://www.openned.com/greenwich-cross-genre-festival. 


\section{Innovative Women's UK Poetry}

Like all such events, these conference festivals have been criticized, the suggestion being that they ghettoize and marginalize women further. This is an argument that continues, on the eve of the publication of the major new all woman anthology due very shortly in 2015, out of everywhere 2 , edited by Critchley.

\section{Anthology-style}

The seminal anthology of innovative women's writing in the UK, out of everywhere, edited by Maggie O'Sullivan, was published in 1996. O'Sullivan is one of most senior and respected poets in the UK and internationally, and this anthology remains a benchmark in UK innovative poetry. It helped locate UK women writers in a field more well represented in the North America, publishing both sets of writers together.

Carrie Etter, editor of a second major such anthology, Infinite Difference: Other Poetries by U.K. Women Poets (2010) argued for the continued need for women's anthologies noting that representation of women in the innovative poetry world lags behind that in its mainstream equivalent, and that many of the problems experienced by women in the '90s and before were still prevalent in 2010 (Etter 2010: 9-13). In this anthology, she also challenges some of the distinctions made between innovative and mainstream poetry by women. Emphasizing new writers, of the twenty-five poets featured, only three had appeared in the O'Sullivan anthology. Etter makes the point that O'Sullivan and Geraldine Monk, another senior and well respected woman poet, both 'respectfully denied [the invitation to contribute to the anthology], on account of the focus on women and the desire not to be categorized.' (11) Independently of one 
Innovative Women's UK Poetry

another, as it turns out.

In 'To Have Done With Women Only Anthologies', Monk writes in response to this and another invitation that 'my predominant response to these invites was one of dispirited gloom...I thought we'd all but done with 'women only' anthologies’ (Monk 2008: 1). While she concedes the value of such anthologies during the 1990s, she notes that:

Slowly but surely the 'women only' publication became a sub-genre rather than a catalyst for change. They gathered together in bookshops - all lined up on separate shelves in their own generic cage. They are still 'other'. And women, it seems, have fully embraced their status as 'other'. In trying to rid ourselves of chains we knitted much stronger ones. Stronger because it is of our own doing. [...] I think it's a travesty. It is time to rid ourselves of this tiresome sub-genre and see it for the paradox it is. 'Women Only' was meant to integrate us not segregate us. [...] what had once been a device for fair representation has now become a shackle. I never realised just how oppressive it had become until I rid myself of it. The irony of it is bemusing: decades spent breaking into the exclusive men's club concludes with having to break out of the exclusive women's club. (2)

With out of everywhere 2, Critchley states that '[t]oday more formally original, politically and philosophically engaged poetry is being written by greater numbers of women than ever before' while making the case for the need for an all-female anthology in the face of 'misogyny still [lurking] not far beneath the surface of what are meant to be some of our most advanced experimental writing and thinking 
Innovative Women's UK Poetry

communities' (Critchley 2015: 9). Of the forty-three poets featured in this book, none have featured in the original O'Sullivan anthology, while twelve also appeared in the Infinite Difference publication.

Part of the gender issue in the innovative poetry world is undoubtedly historical, as has been emphasized by many commentators (several participants in the Wagner moderated Cross-Atlantic Forum, for example), but even this space is contested. Ken Edwards is credited with commenting that in certain reading spaces 'it was implicitly made clear they [women] weren't welcome' (Critchley 2006: 2), for example, while Robert Hampson commented that the 'suggestion of a conscious intent to exclude women poets is at variance with my memory that, on the contrary, there were conscious efforts to include women poets during the 1970s and after' (Hampson 2011: 87). Geraldine Monk has commented that:

I think some male poets did ignore women poets but the majority did not - the dearth was just because there weren't that many women interested in experimentation. They couldn't invite us to read and contribute to magazines if we didn't exist. (Wagner 2007: para 20)

The question of genre and gender has also been an issue. Critchley identified a related poetics based concern connected with visibility:

the conflict between work which is recognisably female or feminist, which involves communicating ‘women’s experience’ explicitly and politically, and 


\section{Innovative Women's UK Poetry}

as such, is embraced by a certain kind of editor or audience [...] and those poets who have wanted, as women, to write challenging, formally progressive poetry, about different or perhaps even the same issues, without being excluded from serious feminist debate or marginalised by their avantgarde peers. (Critchley 2006: 1)

Sadly, many of the issues being spoken about in 2005, and long before, were still being discussed in 2006 and 2010, and indeed are today. Two major episodes on the ukpoetry listserve within the last year immediately spring to mind. One involved the reaction to a male poet at a reading in London whose performance some of the audience found to be offensive to women. Some members of the listserve felt that the response of some male members was inadequate and insensitive. The second concerned the responses by some men on the listserve to the issues raised in the discussion of an open letter to the Internet that commented on rape allegations in the US innovative poetry scene. Many members felt that some of these responses where highly inappropriate, insensitive to women's concerns and highly offensive. As a result, many members, male and non-male left the list in protest, to the extent that the list is perhaps no longer viable in the way it once was.

Critchley notes, though, while flagging the caveat raised by Andrea Brady about online violence towards women, that

there is a contemporary wave of confidence and camaraderie in women's and non-cis and transgender females' innovative writing / feminist / political scenes, facilitated by the public-private slippages the internet allows [...] For 


\section{Innovative Women's UK Poetry}

instance, the formation of an all female British writers' listserv in 2012, inspired by various long-standing American models, has become a necessary hub of writing, thinking, campaigning and supporting activity. (Critchley 2015: 9-10)

\section{Genderless or not?}

Thinking about 'women innovative poets' in the light of Critchley's comment above raises a further important issue: the inseparability of transgender identity from the 'women's' issues raised in the context of UK poetry. It is my sense of the innovative poetry scene as it exists today that such a separation is detrimental to the quality and validity of the struggle for women's rights as persons and as writers, and given the way the discourses and poetics surrounding gender in innovative poetry in the UK have interfaced and exchanged, effectively meaningless. I am not suggesting an equation between 'trans' and 'women' itself as a concept, but rather an equation in key issues of identity space and visibility that gender as a theme linked to 'female', or 'non-cis male', should be, and is, concerned with examining.

For me, excluding or omitting trans writers (whether Male To Female or Female To Male, or without classification) from an article that talks about women's spaces in poetry is the same act as saying that MTF trans people should not be allowed to access female-only social and poetic spaces, or that FTM trans people should not be allowed to access male only social and poetic spaces. As such, it is unconscionable for me as writer and a thinker. From my point of view as a publisher/gate-keeper in the 


\section{Innovative Women's UK Poetry}

innovative poetry world, it is also ill conceived and objectionable. Key terms here are 'trans feminism' (transgender perspectives on feminism, or feminist perspectives on transgender issues) and Transphobia (intolerance of, and prejudice towards, gender diversity). The former is a positive poetic interaction with the spaces of gender in innovative poetry, the latter an ugly blockage in the dynamic practices of poetic exchange that make innovative poetry so crucial to literature as a field. I would suggest the application of these terms in equal measure to men's and to women's poetry.

While the presence, voices and visibility of trans (specifically trans women) writers on, and in relation to, innovative UK poetry has undeniably become, in recent years, increasingly part of the discourse around gender and, importantly, about poetry, this discourse itself is not without its problems. Nat Raha raises a key issue in relation to this:

There's an issue around what is commonly referred to as intersectionality. While recent discussions in the feminist circles of innovative poetry in the UK have been referring to the issue of intersecting oppressions and social hierarchies around race, class, gender with respect to cisgender privilege and trans*/gender non-conforming experiences, ability, academic privilege and educational capital, the positioning of 'women' as the subjugated subjects of social hierarchies within poetry and its discourses - which has much truth does seem to encode the white, cisgender, middle class and university educated woman as the subjugated subject.

These feminist challenges are important, as yes - innovative poetry and its discourses are clearly dominated by white cisgender men. But this form of 


\section{Innovative Women's UK Poetry}

feminism has been alienating to trans*feminists and black/PoC feminists, as myself and others have felt, and feminists from other social positions. Its necessary to be aware of our privileges as feminists, to be able to challenge the social heirarchies that deprive marginal speakers voices. Feminism within innovative poetry needs these voices - it cannot produce an intersectional feminism without bringing them to the fore. The influence that this could have aesthetically and politically is yet to be seen in the UK, but is emerging particularly with the presence of trans* and gender non-conforming poets, and poets who self describe as disabled persons and/or openly address physical and mental health in their work. (Raha 2015)

With multiple identity spaces to be considered in relation to trans as well as in relation to women (and mixed into that we also have sexuality and heteronormativity to bear in mind) gender spaces (in writing and in terms of poetry community structures) these discourses become more and more interconnected, and usefully so.

The Gender is a Glitter anthology (2014), edited by Sophie Mayer and Sarah Crewe, is an instructive response to some of these interconnections. Unlike the anthologies mentioned above, the emphasis here is not on sectioning out gender in a positive or negative way, but rather presenting gender as genderless. David Ashford, of Contraband Books, says of the press that: 'I publish writers I take to be feminists. That is to say, people who are writing rather than just somehow being; moving toward a space of solidarity, as part of a political movement.' He goes on to note that 'the Glitter anthology is not women's poetry nor feminist. It speaks from and to the broader wave of political action that has been opened up by Gender theory'. This 


\section{Innovative Women's UK Poetry}

seems to me a very progressive and timely response to the issues of gender that have surrounded women's poetry in recent years.

\section{Some Relevant Publishing Data ${ }^{4}$}

In the figures that follow - in relation to publishing in UK small presses (the primary, one could say 'only', mode of publication available to innovative poets) - I have adopted as terminology 'cis-male' and 'non-male' as an (unsatisfying) way of distinguishing genders for the purpose of this article. 'Cis-male' refers to males whose experience of their gender matches the sex assigned to them at birth. 'Non-male' seems to me a more inclusive, though admittedly more diametric, term than 'non-cis male', which implies a misalignment of some kind, which I find unhelpful.

Ken Edwards, of Reality Street, publisher of the out of everywhere anthologies, and one of the oldest and most significant publishers of innovative writing in the UK, identifies that $45 \%$ of the single- and dual author poetry publications by the press are by non-male writers.

On Reality Street's policy towards publishing women writers, he notes:

the original impetus did come from Wendy [Mulford] and me and our discussions about exclusion of women from the emerging canons of avant garde writing, so yes there was an inclination towards seeking out women but

\footnotetext{
${ }^{4}$ figures presented here are approximate.
} 


\section{Innovative Women's UK Poetry}

never a dogmatic one. I have continued to try and maintain this balance since Wendy's departure, but never at the expense of quality/excitement. (Edwards 2015)

Tony Frazer, of Shearsman, the biggest and most prolific of innovative poetry publishers in recent years in the UK, and publisher of the Infinite Difference anthology, identifies that (excluding translators and editors) $30-35 \%$ of the publications by the press over the years have been by non-male writers, with the figure for 2015 at $39 \% .40-50 \%$ of the contributors to the Shearsman magazine have been non-male. He also highlights an interesting anomaly in the figures that is telling, perhaps, about the UK innovative poetry scene. Amongst UK authors the percentage of non-male writers is $31 \%$, whereas amongst North American authors $57 \%$ are nonmale. Commenting on this, he says:

I'm always looking for good work by women simply because I don't want Shearsman to be an all-male zone - many of the more 'senior' [female poets] are ensconced with other publishers, and I don't raid other publishing houses [...] My experience with the US has been terrific, however. I get a lot of first or second collections from younger (i.e. under 40) US women, partly, I think, because Shearsman has a demonstrated track-record of taking such authors seriously and fast-tracking them, whereas most US presses operate the pernicious prize-system of entry. (Frazer 2015)

Barque Press, co-run by Andrea Brady and Keston Sutherland is a key publisher of innovative work. $20 \%$ of authors published by the press can be identified as non-male, 


\section{Innovative Women's UK Poetry}

while $14 \%$ of books are by non-male authors.

Brady has said that the press 'has struggled to keep any kind of parity of representation in its own list - that's the historical problem again - but we have tried to support emerging writers, to help women in particular develop the confidence that comes with publication.' (Wagner 2007: para 9), while Sutherland notes:

my sense is that while we never had a policy about gender balance when we first started out, over time we recognized the imbalance of our list and started talking about how we might begin to even things out a bit. We have never adopted a formal policy or quota. The local scene in which we first got started was, it is now widely accepted, largely a homosocial scene without much active critical discussion of gender and sexual politics. Andrea was a vital exception, and she was quicker to recognise the problem with the Barque list than I was. I think we still have plenty of work to do. (Sutherland 2015)

Peter Hughes, of Oystercatcher, one of the most prominent of pamphlet publishers in recent years in the UK, identifies that $30 \%$ of the publications by the press are by nonmale writers. He has taken an active approach to publishing women, commenting that:

Of the first 28 pamphlets only 5 were by women. At that point I must have recognized, belatedly, the imbalance \& I started to request work from women directly. Until then I just let work drift in, usually from unsolicited submissions, \& chose what I liked most. Nearly all the work I received was by men. So I wrote to a bunch of people. So in year 3 (2010) 5 out of the 12 


\section{Innovative Women's UK Poetry}

books are by women. In $201250 \%$ of the Oystercatcher pamphlets were by women. (Hughes 2015)

Tom Chivers, of Penned in the Margins, identifies that the rough proportions are 3:2 cis-male:non-male for authors and books published by his press, which is amongst the highest of the major small presses in the UK. On the publishing of female innovative poets in the UK:

My perspective, such as it is, is that more male writers are published than female. I would certainly like to publish a more balanced proportion, though I am also aware that our figures are considerably more balanced than some in the poetry sector. (Chivers 2015)

Penned in the Margins' policy on submissions, as articulated on their website, is: 'We encourage submissions from all writers, regardless of age, gender, race, religion and background.'

Richard Parker, of Crater Press, has identified that $28 \%$ of authors published by the press can be identified as non-male, while $27 \%$ of books are by non-male authors. (Parker 2015)

Jo Lindsay Walton, who has worked with Marianne Morris at Bad Press, a small press that has published a high proportion of women writers, reports publishing with Sad Press, and its imprints, which he runs with Samantha Walton and Sophie Stamina, 'slightly more women than men [...] We have also - accidentally as far as I can tell, 


\section{Innovative Women's UK Poetry}

but having noticed it I'm keeping it as policy - done larger print runs of the books by women than those by men'. He is also involved in running HIX EROS (with Joe Luna), a review journal dedicated to expanding the depressingly small review culture for innovative work in the UK, and he says in relation to the policy they adopt with this that part of their strategy is 'to prioritise gender above other high level generalising identity characteristics, and to prioritise who is being written about over who is doing the writing. It has played out to slightly more women's work being reviewed than men's work.' (Lindsay Walton 2015)

Although Westhouse Books is now inactive as a publisher, it was an important publisher of innovative poetry between 1996 and 2011. Alan Halsey reports that 20\% of the press's output was by non-male authors. (Halsey 2015)

Various difficulties and complications have been raised repeatedly by (primarily male) publishers in relation to publishing work by non-male writers specifically, with most commenting that it is often more difficult to get work from them, with longer timescales involved, and with more follow-up than with male writers (in general terms). Many acknowledge that some non-male writers do not want to be published by what are sometimes perceived as 'male' run or 'male' focused presses, or are put off by the way these presses operate. In general, the publishers I have spoken to have indicated that approximately two thirds of all unsolicited submissions to these presses come from male authors, as against one third from non-male authors. This certainly has been the case with Veer Books too, although in the last year we have noticed an increase in the number of non-male authors getting in touch about submissions. Richard Parker says of the issue of attracting non-male writers to innovative poetry 


\section{Innovative Women's UK Poetry}

presses: 'I certainly don't think it's a problem that women are generating; and I wouldn't complain to it other than it evidences the fact that I'm doing something wrong.' This is a sentiment echoed by almost all the publishers I have spoken to over the years. The structures and methodologies we employ as a publishing community have been a large part of the problem here, it is recognized. Parker makes the cogent point that 'poetry's always about who you know; this is a part of it, but not all of it' (Parker 2015). As such, the networks we rely on as innovative poets are as important as they have ever been, and are one of those areas that we, as publishers, can look to improve.

\section{Veer Books}

Speaking from my own experience as one of the editors at Veer Books, there are some key points to make about our approach. The first book we published was by Maggie O'Sullivan, and our name came out of our discussion with her and was suggested by Nuri Gene Coz. In the first two years we published four books, two by women, two by men. Since then, looking at the figures, and not including our journals, 17 out of 76 authors can be identified as non-male (22\%), including younger writers such as Rebecca Cremin, Mendoza, Francesca Lisette and Samantha Walton, and more established authors such as Carol Watts, Karen Mac Cormack, Alice Notley and Jennifer Cobbing. 24\% (23 out of 96 books) are by non-male authors. Among these figures 3 of our authors identify as trans ( $4 \%$ of our authors and output to date), including Catherine Hales, Nat Raha and Verity Spott.

With the four journals we have published the proportion is a little higher overall, with $31 \%$ of authors being non-male. This is, overall, lower than some, and similar to other 


\section{Innovative Women's UK Poetry}

presses working in the innovative poetry field in the UK.

While we do recognize the imbalance in innovative poetry publishing and reading spaces in the UK (and, indeed, internationally), we don't set out to publish poets because they are women, men or trans. While we have made a point of looking at the work of more non-male writers and encouraging them to submit work for publication, we don't have a policy of positive action or positive discrimination in play, and whether a text is published or not doesn't have any gender considerations involved. Our emphasis is on excellent poetry and work deserving of encouragement for attempting to push boundaries.

What we have noticed recently is a marked increase in the number of submissions and enquiries about submissions from non-male writers. Our publishing schedule for 2015 reflects this; while it is constantly being updated, so far this year, either published or in the pipeline, we have five non-male poets, which amounts $50 \%$ of those planned for 2015 at this point (Rosa van Hensbergen, Patricia Farrell, Frances Kruk, Holly Pester, and Jennifer Pike Cobbing). This is an indication of the increasing number of interesting texts (that happen to be by non-male writers) that have come to us as publishers.

We do have a stated commitment to seeking out more young and 'new' (in terms of their publishing) writers producing interesting work, and perhaps this is part of the new situation innovative poetry in the UK finds itself in. From Veer's point of view, some of the most exciting work on the innovative scene over the last twelve months or so has been by young non-male writers such as Frances Kruk, Verity Spott, Holly Pester, Nat Raha, Rosa van Hensbergen, for example, and we have been very happy to 


\section{Innovative Women's UK Poetry}

publish and promote their work, alongside a range of other writers. It's very much about the writing, for us, and in each of these cases, and indeed all the authors we have published over the years, the writing speaks for itself. One step we have taken is to remove the 'we are closed for submissions' notice from our website and our operation, as we feel that this discourages newer and less confident writers disproportionally (and non-male writers disproportionally within that). As with most presses, there are also specific writers whose work interests us and who we would like to publish (where the text in question fits Veer's current direction, naturally) Elizabeth James is just one example - not because she is female, but because we really like her writing, and feel that her work is a good fit with Veer. In terms of writing, Veer poets 'steer beyond the bracketed edge', as Ulli Freer puts it, and we're very strongly in favour of these non-bracketed spaces.

I should note that publishing writers who identify as trans is not a badge of honour for us at Veer - the work speaks for itself - but we do support trans rights very strongly, and that point is worth making.

\section{An Outlook}

In terms of the now, there certainly appears to be more innovative writing in poetry being produced by young and new non-male writers, and, importantly, being submitted for publication. Other publishers in the field echo this experience. Monk's point, in her 'To Have Done With Women Only Anthologies' paper, that '[w]omen are now editors, reviewers and organisers of events and perhaps most significantly becoming a vital force on the creative writing courses in universities and college where poetry now lives' (Monk 2008: 2), is also emphasized by other 


\section{Innovative Women's UK Poetry}

commentators, including the editors of the main recent anthologies of women's innovative UK poetry (Etter 2010: 11, Critchley 2007: 52) They are also publishers, with numerous small presses wholly or co-run and edited by women.

This increase in activity by women in the gate-keeper positions within the innovative poetry world is an essential point when thinking about the scape of innovative women's writing today in the UK, whatever your response to all-women anthologies may be. It matters, and we have indeed seen an upsurge in women writers' poetic activity and in the activities related to the structures of the innovative poetry world in the UK (academic and non-academic).

Presses wholly or co-run by women include Barque (Andrea Brady), Bad Press (Marianne Morris), Stinky Bear Press (Mendoza, Sarah Crew), Ninerrors' poetry series (Mendoza), yt communications (Frances Kruk), Iodine (Verity Spott), Tipped Press (Rosa van Hensbergen) to name a few. Carol Watts, Emily Critchley, Mendoza, Becky Cremin, Jessica Pujol and many others are involved in organizing and running events, readings and groupings. Vicky Sparrow, Sophie Robinson, Sophie Mayer, Sarah Crewe, Lila Matsumoto and many others fill editorial roles. The number of female innovative poets in academic positions within UK universities continues to rise (Carol Watts in Birkbeck, Redell Olson in RHUL, Andrea Brady in Queen Mary, Zoë Skoulding in Bangor, Emily Critchley in Greenwich, Sophie Robinson in UEA, Jennifer Cooke in Loughborough, Samantha Walton at Bath Spa, Holly Pester in Essex, for example, not to mention the large number of PhDs in the pipeline or already completed).

Zoë Skoulding, in describing her approach to women's poetry and urban space, offers a useful way to think about the scape of innovative women's poetry: 'The term 


\section{Innovative Women's UK Poetry}

'women writer' is used here to describe a particular set of coordinates, but not to limit the ways in which this position may be inhabited' (Skoulding 2013: 16). She also quotes Rachel Blau DuPlessis from her critical book Blue Studios, which I think is relevant here, where she says that 'Feminism in poetry is absolutely not one position' (6). In terms of addressing the issues and inequalities around 'women's innovative poetry in the UK', it is clear that there is not one way, but many, to address these issues. And not just that, there is not one gender at risk here, but many.

Pretty much every publisher I have spoken to over the last several years, as well as specifically in relation to this article, have expressed an awareness of the issues surrounding gender and publishing, and a desire to improve their presses' addressing of these. The methods vary, but I have found that, across the board, there is strong support for the publication of more innovative writing by women and non-male writers, and the willingness to publish these writers through their presses. 
Innovative Women's UK Poetry

\section{Works Cited}

Ashford, D (2015), Personal communication, 11 April 2015.

Chivers, T (2015), Personal communication, 8 April 2015.

Critchley, E (2007), 'A conference overview \& introductory remarks', in 'Cambridge Experimental Women's Poetry Festival 5 - 9 October 2006'. HOW2, 3 (1), at https://www.asu.edu/pipercwcenter/how2journal/vol_3_no_1/cambridge/ (accessed 16 April 2015).

Critchley, E (ed.) (2006), ThesePagesAreMarkedByWomen, Cambridge:

Contemporary Experimental Women's Poetry Festival 2006.

- (2015), out of everywhere 2, Hastings: Reality Street. 


\section{Innovative Women's UK Poetry}

Edwards, K (2015), Personal communication, 11 April 2015.

Etter, C (ed.) (2010), Infinite Difference: Other Poetries by U.K. Women Poets, Exeter: Shearsman.

Frazer, T (2015), Personal communication, 7 April 2015.

Halsey, A (2015), Personal communication, 7 April 2015.

Hampson, R (2011), 'Lost and Found: Women's Poetry and the Academy', Journal of British and Irish Innovative Poetry, 3 (2), pp. 81-90.

Hughes, P (2015), Personal communication, 7 April 2015.

Kennedy, D \& C Kennedy (2013), Women's Experimental Poetry in Britain 19702010, Liverpool: Liverpool University Press.

Lindsay Walton, Jo (2015), Personal communication, 19 April 2015.

Monk, G (2008), ‘To Have Done With Women Only Anthologies', in Midsummer Poetry Festival - Symposium (2014), Sheffield: Bank Street Arts.

O'Sullivan, M (ed.) (1996), out of everywhere, London: Reality Street Editions.

Parker, R (2015), Personal communication, 8 April 2015. 
Innovative Women's UK Poetry

Raha, Nat (2015), Personal communication, 23 April 2015.

Sheppard, R \& S Thurston (2009), 'Editorial', Journal of British and Irish Innovative Poetry, 1 (1).

Skoulding, Z (2013), Contemporary Women's Poetry and Urban Space, Basingstoke: Palgrave MacMillan.

Sutherland, K (2015), Personal communication, 7 April 2015.

Thurston, S (2015), 'Contemporary innovative poetry by women in the UK: Revoicing in the work of Holly Pester, SL Mendoza and Sophie Robinson', Contemporary Women's Writing, $9(1)$, pp 53-72.

Wagner, C (ed.) (2007), 'Women and the UK Experimental/Avant-Garde Poetry Community - A Cross-Atlantic Forum', Jacket, 34, at http://jacketmagazine.com/34/wagner-forum.shtml (accessed 16 April 2015) 